\title{
ANALISIS STATUS GIZI SISWI SEKOLAH DASAR DI KENAGARIAN AIR BANGIS KABUPATEN PASAMAN BARAT
}

\author{
Sefri Hardiansyah \\ Program Studi Pendidikan Jasmani Kesehatan dan Rekreasi, Fakultas Ilmu Keolahragaan, \\ Universitas Negeri Padang \\ Jl. Prof. Dr. Hamka Kampus Air Tawar Padang \\ Email: hardiansyah@fik.unp.ac.id
}

\begin{abstract}
ABSTRAK
Permasalahan dalam penelitian ini adalah kurangnya aktivitas gerak yang dilakukan oleh para siswi dalam pelaksanaan pembelajaran Penjasorkes pada tingkat Sekolah Dasar di Kenagarian Air Bangis Kabupaten Pasaman Barat. Kurangnya aktivitas gerak dalam pelaksanaan pembelajaran Penjasorkes tersebut kemungkinan disebabkan oleh rendahnya status gizi siswa. Penelitian ini termasuk penelitian deskriptif yang bertujuan untuk mengetahui tingkat status gizi siswi di Sekolah Dasar yang berada di Kenagarian Air Bangis Kabupaten Pasaman Barat. Populasi dalam penelitian ini adalah seluruh siswa kelas IV dan V Sekolah Dasar kelas yang ada di Kenagarian Air Bangis Kabupaten Pasaman Barat dengan jumlah 168 orang yang terdiri dari 7 Sekolah Dasar. Teknik penarikan sampel dengan menggunakan teknik purposive sampling sehingga sampel dalam penelitian ini berjumlah 59 orang. Data dikumpul melalui pengukuran berat badan dan tinggi badan dan menggunakan rumus Indeks Masa Tubuh (IMT). Data dianalisis dengan menggunakan rumus persentase. Dari hasil penelitian dapat diketahui bahwa sebagian besar status gizi siswi sekolah dasar di Kenagarian Air Bangis Kabupaten Pasaman Barat berada pada kategori normal dengan jumlah siswa sebanyak 46 orang dengan persentase sebesar $77.97 \%$..
\end{abstract}

Kata kunci: status gizi, siswi sekolah dasar

\section{PENDAHULUAN}

Pembangunan Nasional pada hakekatnya membangun manusia Indonesia seutuhnya dan masayrakat Indonesia secara menyeluruh. Manusia Indonesia seutuhnya adalah manusia yang sehat kuat jasmani dan rohani serta mampu menjadi motor pembangunan, sehingga pembangunan tersebut benar-benar dapat dirasakan oleh seluruh rakyat dan dilaksanakan merata di seluruh tanah air. Keberhasilan pengembangan nasional sangat ditentukan olah sumber daya manusia, baik sebagai subjek maupun objek dari pembangunan itu sendiri, dengan demikian upaya peningkatan sumber daya manusia baik sebagai sasaran maupun sebagai tujuan pembangunan perlu mendapat perhatian utama .

Dalam rangka meningkatkan sumber daya manusia Indonesia yang berkualitas, di bidang pendidikan, pemerintah telah menetapkan fungsi dan tujuan pendidikan nasional sebagai mana dinyatakan dalam UU RI No. 20 tentang Sistim Pendidikan Nasional (2003): 


\begin{abstract}
"Pendidikan Nasonal berfungsi mengembangkan kemampuan dan membentuk watak serta peradaban bangsa yang bermartabat dalam rangka mencerdaskan kehidupan bangsa , bertujuan untuk berkembangnya potensi perserta didik agar menjadi manusia yang beriman dan bertakwa kepada Tuhan Yang Maha Esa, berakhlak mulia, sehat, berilmu, cakap kreatif, mandiri dan menjadi warga negara yang demokratis serta bertanggung jawab".
\end{abstract}

Pada saat ini kegiatan belajar mengajar yang dilaksanakan di sekolah termasuk kedalam kegiatan yang sangat melelahkan dimana guru dan siswa harus mengikuti PBM kurang lebih 78 jam setiap hari di luar jadwal ekstrakurikuler, dengan banyak aktivitas yang dilakukan oleh guru dan siswa tersebut tentu akan membutuhkan asupan gizi yang tinggi agar kegiatan siswa dan guru dalam sehari-hari dapat berjalan dengan baik.

Asupan gizi mempunyai dampak terhadap kegiatan sehari-hari, dengan asupan gizi yang mencukupi maka guru dan siswa akan memiliki semangat yang lebih dalam melakukan aktivitas sehari-hari, sebaliknya apabila kebutuhan gizi guru dan siswa tidak tercukupi maka akan berdampak buruk terhadap kinerja dan semangat guru dan siswa dalam menjalankan aktivitas sehari-hari. Gizi yang tidak tercukupi dengan baik dengan waktu yang lama maka akan berdampak buruk terhadap status gizi, oleh sebab itu agar dapat memiliki statuts gizi yang baik maka asupan gizi yang dibutuhkan oleh tubuh harus dipenuhi setiap hari.

Status gizi pada setiap orang berbeda-beda karena berhubungan dengan kecukupan gizi yang dikonsumsi setiap hari dan juga dipengaruhi oleh faktor umur, jenis kelamin, genetik, berat dan tinggi badan dan aktivitas dan keadaan kesehatann (Karyadi, 1996) oleh karena itu, status gizi sangat perlu diperhatikan bagi guru dan siswa, mengingat hal tersebut merupakan faktor yang sangat penting untuk kesehatan dan kebugaran, sehingga akan dapat meningkatkan prestasi belajar, namun hal ini belum tentu dapat terpenuhi mengingat sebagian besar guru terlalu disibukkan dengan aktivitas sehari-hari di sekolah dan dikeluarga serta siswa yang sering mengkonsumsi makanan sembarangan dan juga terbatasnya pengetahuan guru dan siswa dibidang gizi.

Kenagarian Air Bangis merupakan salah satu wilayah yang menyelenggarakan pelaksanaan proses belajar mengajar di Sekolah Dasar, di wilayah tersebut terdapat 7 Sekolah Dasar. Berdasarkan pengamatan dan wawancara penulis dengan beberapa orang siswa dan guru yang berada pada Kenagarian Air Bangis, penulis memperoleh informasi bahwa siswi sekolah dasar di kenagarian Air Bangis banyak yang memiliki aktivitas gerak yang rendah terutama dalam pelaksanaan pembelajaran penjasorkes hal ini dibuktikan dengan masih banyak siswi yang duduk-duduk dan cenderung malas untuk bergerak. Kurangnya aktivitas gerak yang dilakukan siswi dapat dipengaruhi oleh beberapa faktor diantaranya adalah keadaan status gizi siswi, motivasi, tingkat kesegaran jasmani serta keadaan lingkungan sekolah.

Dari uraian di atas, maka penulis tertarik untuk mengadakan penelitian yang berkaitan dengan masalah tersebut di atas. Dari penelitian ini diharapkan bisa melahirkan suatu langkah antisipatif terhadap permasalahan yang terjadi saat pembelajaran Penjasorkes pada Sekolah Dasar di Kenagarian Air Bangis.

\title{
TINJAUAN PUSTAKA
}

\section{Status Gizi}


Khumadi (1994) mengemukakan bahwa: Status Gizi adalah "keadaan seseorang yang diakibatkan oleh konsumsi, penyerapan dan penggunaan zat gizi dari makanan dalam jangka waktu yang lama". Bobot (berat) adalah salah satu parameter penting dalam menentukan status kesehatan manusia, khususnya yang berhubungan dengan status gizi. Status gizi merupakan ukuran keadaan gizi pada seseorang dan juga pada sekelompok orang. Status gizi pada setiap orang berbeda-beda karena berhubungan dengan kecukupan gizi yang dikonsumsi setiap hari dan juga dipengaruhi oleh faktor umur dan juga jenis kelamin (Wirjatmadi, 1998).

Dari beberapa pendapat di atas maka dapat disimpulkan bahwa status gizi merupakan keadaan gizi seseorang yang dipengaruhi oleh keadaan makanan yang dikonsumsi setiap hari. Status gizi pada seseorang sangat besar pengaruhnya terhadap penampilan. Bagi siswa, status gizi yang tergolong baik sudah barang tentu akan dapat berpengaruh pada peningkatan penampilannya dan ini sangat diperlukan untuk memperoleh kondisi fisik yang prima dan juga berpengaruh terhadap prestasi belajar.

Untuk mengetahui status gizi perlu dilakukan penilaian dengan berbagai cara antara lain pemeriksaan klinis, antropometri, laboratorium dan penilaian konsumsi makanan (Depkes, 1993). Dari berbagai cara pengukuran status gizi ini, maka yang sering dilakukan adalah dengan cara antropometri karena pelaksanaannya mudah dan tidak memerlukan peralatan yang rumit. Pengukuran antropomotri adalah pengukuran yang dilakukan terhadap tubuh seseorang dengan jalan mengukur tinggi badan (TB) dan berat badan (BB), kedua hal ini sering disebut BB/TB (Lisdiana, 1998). Pelaksanaan penimbangan berat badan sangat mudah dilakukan dengan cara seseorang berdiri diatas timbangan berat badan dalam keadaan berdiri tanpa baju dan alas kaki kemudian dilihat angka berapa yang ditunjuk oleh jarum timbangan maka itulah angka berat badannya (kg). Kemudian pengukuran tinggi badan juga hampir sama, seseorang berdiri tegak dengan pandangan lurus ke depan kemudian diukur tingginya dengan menggunakan meteran untuk mengukur tinggi badan. Parameter yang digunakan daalam penelitian ini adalah Indek Massa Tubuh (IMT) dengan rumus:

$$
I M T=\frac{\operatorname{BeratBadan}(\mathrm{kg})}{\text { TinggiBadan }(m) x \operatorname{Ting} \operatorname{BBadan}(\mathrm{m})},
$$

Untuk anak tingkat sekolah dasar Indeks Masa Tubuh tersebut akan dikonfersikan berdasarkan tabel penilaian status gizi Antropometeri WHO-NCHS, sebagai berikut:

Tabel 1. Klasifikasi Status Gizi Antropometeri WHO-NCHS

\begin{tabular}{|c|c|l|}
\hline Indeks & Ambang Batas (Z-Score) & Kategori Status Gizi \\
\hline Indeks Masa & $<-3 S D$ & Sangat Kurus \\
\cline { 2 - 3 } Tubuh menurut & $-3 \mathrm{~s} / \mathrm{d}<-2 \mathrm{SD}$ & Kurus \\
\cline { 2 - 3 } Umur (IMT/U) & $-2 \mathrm{~s} / \mathrm{d}+1 \mathrm{SD}$ & Normal \\
\cline { 2 - 3 } Anak Umur 5- & $>1 \mathrm{~s} / \mathrm{d}+2 \mathrm{SD}$ & Gemuk \\
\cline { 2 - 3 } 18 Tahun & $>2 \mathrm{SD}$ & Obesitas \\
\hline
\end{tabular}

Penimbangan berat badan perlu dilakukan secara teratur, karena dengan menimbang berat badan secara teratur akan dapat diketahui kecukupan gizi dan juga aktivitas yang akan dilakukan, ke dua hal ini harus seimbang. Apabila aktivitas berat dan 
berlangsung lama sedangkan asupan energi sangat sedikit, maka akan dapat menyebabkan menurunnya berat badan dan akhirnya akan berpengaruh terhadap status gizi. Setelah mengetahui status gizi, maka bagi siswa yang mengalami status gizi kurang maka ada beberapa hal yang harus dilakukan untuk meningkatkan status gizinya antara lain:

a. Pemenuhan energi harus sesuai dengan tingkat umur, jenis kelamin dan tingkat aktivitas

b. Makan harus bervariasi dan cukup zat gizinya

c. Susunan makan atau menu harus sesuai dengan kebiasaan makan siswa dan jadwal latihan.

d. Kadar hemoglobin $(\mathrm{Hb})$ dapat ditingkatkan dengan banyak memakan makanan yang kaya akan zat besi terutama yang berasal dari hewani (Depkes, 2003).

\section{Kecukupan Energi}

Agar dapat hidup sehat dan dapat mempertahankan kesehatan yang prima maka faktor gizi sangat menentukan. Untuk itu maka jumlah zat gizi yang diperoleh oleh tubuh melalui makanan yang kita makan sehari-hari harus mencukupi kebutuhan baik untuk kebutuhan tubuh itu sendiri maupun untuk aktivitas harian dan olahraga.

Pemberian gizi yang tepat bagi siswa tidaklah mudah sebab banyak faktor yang ikut menentukan seperti budaya makan, pengetahuan tentang gizi, ketersediaan bahan makanan dan lainnya. Para ahli sependapat bahwa kita harus mengkonsumsi makanan sesuai dengan kebutuhan individu sehari-hari atau gizi seimbang, sebab apabila tidak seimbang gizi yang kita masukkan dengan aktivitas atau kegiatan yang dilakukan maka akan dapat menimbulkan kelainan pada tubuh seperti bertambahnya berat badan ataupun menimbulkan penyakit pada tubuh. Marsetyo (1991), kekurangan karbohidrat, lemak dan protein akan menimbulkan kurangnya energi pada tubuh, akibatnya tubuh akan menjadi lesu, kurang gairah untuk melakukan berbagai kegiatan, kondisi tubuh seperti ini akan menimbulkan kerugian seperti malas bekerja, malas untuk mencari nafkah dan menurunnya prestasi.

Begitu juga sebaliknya apabila berlebih, maka energi ini akan disimpan menjadi energi cadangan (lemak) oleh tubuh, apabila keadaan ini berlangsung cukup lama maka lemak ini akan menjadi beban pada tubuh dan membuat orang susah bergerak karena gemuk dan akan disusul oleh berbagai penyakit seperti jantung kroner, strok dan lainnya (Lisdiana, 1998).

Di samping itu yang perlu diperhatikan adalah keseimbangan dari zat gizi seperti karbohidrat, lemak dan protein. Kebutuhan zat gizi untuk olahragawan adalah sebagai berikut, Karbohidrat $60-70 \%$ dari total kalori, Lemak $20-25 \%$ dari total kalori dan Protein sebanyak 10 - $15 \%$ dari total kalori (Depkes, 1997). Kemudian makanan yang kita makan setiap hari harus bervariasi baik makan pagi, siang maupun makan malam. Dengan bervariasinya makanan ini maka akan dapat menutupi kekurangan suatu zat gizi pada tubuh, sebab masing-masing bahan makanan mempunyai kekurangan dan kelebihan zat gizi. Adapun zat gizi yang kita butuhkan setiap hari adalah sebagai berikut:

\section{a. Karbohidrat}

Karbohidrat merupakan sumber energi utama dan memegang peranan sangat penting untuk seorang siswa dalam melakukan olahraga. Karbohidarat dibutuhkan oleh siswa sebanyak 60 sampai $70 \%$ dari total kebutuhan energi setiap hari (Depkes, 2000). Untuk berolahraga, maka energi berupa ATP dapat diambil dari karbohidrat yang terdapat dalam tubuh berupa glukosa dan glikogen yang disimpan dalam otot maupun di hati 
Glikogen otot dipergunakan langsung oleh otot untuk pembentukan energi, sedangkan glikogen yang disimpan dalam hati akan mengalami perubahan menjadi glukosa yang akan masuk ke dalam peredaran darah, dan selanjutnya dipergunakan oleh otot. Sumber karbohidrat diperoleh dari bahan makanan pokok seperti beras, sagu, talas, jagung, ubi, gandum, gula serta hasil olahannya.

Pemberian karbohidarat bagi siswa bertujuan untuk mengisi kembali simpanan glikogen yang ada di otot dan hati yang telah dipakai pada saat kontraksi otot waktu latihan. Bagi siswa yang mempunyai simpanan glikogen sedikit maka akan cepat merasa lelah dan kurang dapat berprestasi. Dalam menkonsumsi karbohidrat sebaiknya dalam bentuk karbohidarat kompleks, sedangkan karbohidrat sederhana hanya sedikit. Karbohidrat kompleks terutama banyak terdapat dalam bahan makanan yang berasal dari tumbuhtumbuhan seperti nasi, kentang, roti, ubi, jagung, singkong dan lain-lain. Disamping mengandung karbohidrat kompleks juga banyak mengandung vitamin dan mineral, elain itu karbohidrat juga lama dicerna dan diserap secara perlahan serta banyak disimpan dalam bentuk glikogen yang setiap saat dapat dipergunakan. Makanan karbohidrat sederhana banyak terdapat dalam bahan makan berupa gula, sirup permen, coklat, selai, cake. Karbohidrat sederhana ini kurang bergizi karena tidak mengandung vitamin dan mineral. Disamping itu karbohidrat sederhana cepat dicerna dan diserap sehingga dapat mempercepat peningkatan glukosa darah dan juga cepat menurunkan glukosa darah sehingga atliet cepat merasa lelah (Depkes, 1997).

\section{b. Lemak}

Lemak sebetulnya merupakan sumber atau penghasil energi yang paling besar jika dibandingkan dengan yang lainnya, disamping itu juga berfungsi sebagai pelarut vitamin A, D, E, dan K (Karyadi, 1996). Pengolahan lemak didalam tubuh cukup lama dan tidak secepat karbohidrat, maka lemak ini disimpan sebagai cadangan energi. Pada olahraga dengan intensitas sedang dalam waktu yang lama misalnya olahraga endurance maka lemak dapat dipergunakan. Sedangkan untuk cabang olahraga berat dengan waktu yang singkat maka lemak tidak bisa dipergunakan, sebab pemecahan asam lemak untuk menjadi energi membutuhkan oksigen yang lebih banyak dari pada karbohidrat. Penggunaan lemak ini dengan cara tubuh memecah lemak menjadi asam lemak dan gliserol. Asam lemak bebas akan diangkut kejaringan dan ke otot dan akan dipergunakan sebagai sumber energi.Lemak dibutuhkan oleh siswa setiap hari sebanyak 20 sampai $25 \%$ dari total kebutuhan energi setiap hari (Depkes, 2000).

Sumber lemak dapat berasal dari hewani dan nabati. Makanan yang berasal dari lemak hewani banyak terdapat bahan makanan padat seperti daging, lemak, keju dan lainlain. Kemudian ada juga lemak yang berasal dari tumbuh-tumbuhan seperti minyak kelapa, minyak jagung, minyak kacang, minyak bunga matahari, minyak zaitun dan minyak wijen (Depkes, 1997).

\section{c. Protein}

Protein juga penghasil energi, tetapi fungsi utamanya adalah untuk pembangun dan mengganti sel-sel yang rusak pada tubuh. Budiyanto (2001) mengatakan bahwa protein dalam olahraga tidak berperan penting karena hanya $5-10 \%$ dari total energi yang dikeluarkan berasal dari protein, dan Protein baru digunakan untuk energi apabila energi dari karbohidrat dan lemak sudah tidak mencukupi, apabila energi yang kita pergunakan sudah berasal dari protein maka hal ini sangat merugikan pada tubuh sebab akan dapat 
menimbulkan kelainan pada tubuh itu sendiri. Protein dibutuhkan oleh siswa setiap hari sebanyak 10 sampai $15 \%$ dari total kebutuhan energi setiap hari (Depkes, 2000).

Protein terdiri dari beberapa asam amino esensial yang tidak dapat dibuat oleh tubuhsehingga harus diperoleh dari makanan sumber protein, sedangkan protein non esensial dapat dibuat oleh tubuh. Protein banyak didapat baik dalam bentuk hewani maupun nabati seperti ikan, tahu, tempe, daging, telur, susu, produk susu, kacang-kacangan, kacang tanah, kedelai, kacang hijau dan lainnya.

Protein yang berasal hewani dapat mensuplai semua asam amino esensial, sebaliknya protein yang berasal nabati hanya mempunyai sebahagian asam amino esensial dan kualitasnya kurang baik. Namun makanan yang berasal dari hewani harus kita waspadai dan jangan mengkonsumsinya secara berlebihan, karena disamping mengandung asam amino esensial juga mengandung lemak dan koleterol tinggi yang dapat memicu terjadinya penyakit jantung dan stroke. Siswa tidak boleh menkonsumsi protein berlebihan, karena asupan protein yang berlebihan akan diubah menjadi lemak badan, dan disamping itu dapat menyebabkan anak mengalami diuresis yang berlebihan sehingga dapat menyebabkan dehidrasi.

d. Air

Faktor yang memegang peranan pentingdalam tubuh terutama dalam pemeliharaan fungsi tubuh, baik pada tingkat sel, jaringan, organ, maupun fungsi tubuh secara keseluruhan adalah air. Di samping itu air berperan dalam tahap-tahap metabolisme, terutama sebagai kofaktor aktivitas enzim-enzim. Fungsi air bagi tubuh adalah: pelarut dan alat angkut, katalisator, pelumas, fasilitator pertumbuhan, pengatur suhu dan peredam benturan.

Dalam pengaturan panas tubuh, air memang peranan penting, pembakaran unsurunsur gizi di dalam tubuh mengakibatkan naiknya suhu badan. Untuk menurunkan panas badan menjadi normal kembali, sebagian air harus di keluarkan dari lubang-lubang keringat. Untuk menguapkan air di perlukan panas, dan panas ini di ambil dari kelebihan panas tubuh yang di akibatkan pembakaran sehingga panas badan akan turun kembali. Air yang ada dalam tubuh di peroleh dari berbagai sumber yaitu:

- Air yang di dapat dari air minum

- Air yang di dapat dari bahan-bahan makanan

- Air yang di dapat dari sisa pembakaran hidrat arang, lemak, dan protein.

Air yang tidak di gunakan lagi oleh tubuh di buang melalui berbagai alat pembuangan, yaitu ginjal, lubang keringat,dan paru-paru sebagai uap air. Air yang di buang melalui berbagai alat pembangunan ini selalu dalam keadaan seimbang. Udara panas, jumlah air yang di keluarkan lewat lubang keringat menjadi banyak untuk menurunkan suhu badan, sedangkan yang di buang lewat ginjal menjadi sedikit. Dengan cara demikian tubuh terhindar dari bahaya kekurangan air atau dehidrasi. Menurut Sjahmien Moehji,B.Sc (1986:62).

Tabel 2. Gizi yang Dianjurkan Untuk Indonesia

\begin{tabular}{|l|l|l|l|l|l|l|l|}
\hline Golongan & $\begin{array}{l}\text { Energi } \\
\text { Kalori }\end{array}$ & $\begin{array}{l}\text { Protein } \\
\text { Gram }\end{array}$ & $\begin{array}{l}\text { Kalsium } \\
\text { Gram }\end{array}$ & $\begin{array}{l}\text { Besi } \\
\text { Gram }\end{array}$ & $\begin{array}{l}\text { Vit A } \\
\text { Mg }\end{array}$ & $\begin{array}{l}\text { Vit B 1 } \\
\text { MG }\end{array}$ & $\begin{array}{l}\text { Vit C } \\
\text { mg }\end{array}$ \\
\hline $\begin{array}{l}\text { Remaja } \\
\text { Wanita }\end{array}$ & & & & & & & \\
\hline
\end{tabular}




\begin{tabular}{|l|l|l|l|l|l|l|l|}
\hline 10-12 tahun & 2300 & 59 & 0,7 & 12 & 3450 & 0,9 & 60 \\
13-15 tahun & 2100 & 58 & 0,7 & 12 & 3600 & 1,0 & 60 \\
$16-19$ tahun & 2100 & 57 & 0,6 & 12 & 4000 & 0,8 & 60 \\
\hline Remaja Pria & & & & & & & \\
$10-12$ tahun & 2300 & 50 & 0,7 & 12 & 3450 & 0,9 & 60 \\
$13-15$ tahun & 2900 & 58 & 0,7 & 12 & 4000 & 1,1 & 60 \\
$16-19$ tahun & 2900 & 65 & 0,6 & 12 & 4000 & 1,2 & 60 \\
\hline
\end{tabular}

Sumber : Departemen Kesehatan Republik Indonesia

\section{e. Vitamin}

Vitamin adalah zat-zat organic kompleks yang di butuhkan dalam jumlah yang sangat kecil dan pada umumnya tidak dapat di bentuk oleh tubuh, harus di datangkan dari makanan. Fungsi vitamin sebagai zat pengatur pertumbuhan dan pemeliharaan kehidupan. Masing-masing vitamin mempunyai fungsi spesifik di dalam tubuh, karena vitamin merupakan zat organic maka vitamin dapat rusak karena penyimpanan dan pengelolaan. Sebelum mengetahui susunan kimianya, vitamin di beri nama menurut abjad (A,B,C,D,E,K). Hasil penelitian membedakan vitamin dalam dua kelompok : 1) vitamin larut dalam lemak (vitamin A,D,E, dan K), 2) vitamin larut dalam air (vitamin B dan C ). Vitamin berperan dalam beberapa tahap reaksi metabolism energi, pertumbuhan dan pemeliharaan tubuh, pada umumnya sebagai koenzim atau sebagai bagian dari enzim.

\section{METODOLOGI PENELITIAN}

\section{Jenis Penelitian}

Penelitian ini termasuk pada penelitian Deskriptif, yaitu mendiskripsi tentang status gizi guru dan siswa Sekolah Dasar di Kenagarian Air Bangis Kabupaten Pasaman Barat.

\section{Populasi dan Sampel}

\section{a. Populasi}

Menurut Sugiyono (2008: 117) populasi adalah wilayah generalisasi yang terdiri atas obyek/subyek yang mempunyai kualitas dan karakteristik tertentu yang ditetapkan oleh peneliti untuk dipelajari dan kemudian ditarik kesimpulannya". Hal yang hampir serupa dikatakan Arikunto (1998: 8) mengatakan "populasi adalah keseluruhan subjek penelitian. Populasi dalam penelitian ini adalah selurus siswa kelas IV dan V Sekolah Dasar di Kenagarian Air Bangis kabupaten pasaman barat yang berjumlah 164.

\section{b. Sampel}

Sampel adalah bagian dari populasi yang menjadi pusat perhatian penelitian, dalam ruang lingkup dan waktu yang telah ditentukan, Winarno (2011: 83). Teknik penarikan sampel yang dilakukan dalam penelitian ini adalah dengan menggunakan teknik purposive sampling yaitu dengan mempertimbangkan jenis kelamin dimana sampel dalam penelitian ini hanya siswa sekolah dasar yang berjenis kelamin perempuan sehingga jumlah sampel dalam penelitian ini sebesar 59 orang.

\section{Instrumen Penelitian}

Instrumen yang digunakan untuk mengukur status gizi adalah standar Indeks Massa Tubuh yang sudah standar Indonesia (IMT) dengan rumus sebagai berikut:

$$
I M T=\frac{\operatorname{BeratBadan}(\mathrm{kg})}{\text { TinggiBadan }(m) x \operatorname{Ting} g i \operatorname{Badan}(\mathrm{m})}
$$


Pelaksanaan penimbangan berat badan sangat mudah dilakukan dengan cara seseorang berdiri di atas timbangan berat badan dalam keadaan berdiri tanpa baju dan alas kaki kemudian dilihat angka berapa yang ditunjuk oleh jarum timbangan maka itulah angka berat badannya $(\mathrm{kg})$.

Kemudian pengukuran tinggi badan juga hampir sama, seseorang berdiri tegak dengan pandangan lurus ke depan, kemudian diukur tingginya dengan menggunakan meteran untuk mengukur tinggi badan. Untuk menentukan status gizi, maka angka yang didapat dari hasil IMT ini dicocokkan dengan Antropometeri WHO-NCHS untuk anak usia sekolah dasar.

\section{Tekhnik Analisa Data}

Tekhnik analisa data yang dilakukan dalam penelitian ini dengan analisa statistitik deskriptif/persentase:

$$
\begin{aligned}
& \mathrm{P}=\frac{F}{N} \chi 100 \% \\
& \mathrm{P}=\text { persentase } \\
& \mathrm{F}=\text { frekuensi } \\
& \mathrm{N}=\text { Jumlah sampel }
\end{aligned}
$$

\section{HASIL DAN PEMBAHASAN}

\section{a. Hasil Penelitian}

Hasil dari penelitian ini adalah deskripsi data atau gambaran keadaan status gizi siswi Sekolah Dasar di Kenagarian Air Bangis Kabupaten Pasaman Barat, adapuan deskripsi data tersebut adalah sebagai berikut: Dari hasil pengukuran yang dilakukan terhadap siswiSekolah Dasar di Kenagarian Air Bangis diperoleh rata-rata berat badan siswa adalah $25.25 \mathrm{~kg}$, rata-rata tinggi badan sebesar $125.39 \mathrm{~cm}$ dan rata-rata IMT sebesar 15.93. Untuk lebih jelasnya distribusi data status gizi siswiSekolah Dasar di Kenagarian Air Bangis ini dapat dilihat pada tabel di bawah ini.

Tabel 3. Distribusi Frekuensi Data Status Gizi Siswa Putri

\begin{tabular}{|c|c|c|l|}
\hline $\begin{array}{c}\text { Batas } \\
\text { Pengelompokan }\end{array}$ & Fa & Fr(\%) & Klasifikasi \\
\hline$<-3 S D$ & 3 & 5.08 & Sangat Kurus \\
\hline-3 s/d <-2SD & 5 & 8.47 & Kurus \\
\hline-2 s/d +1SD & 46 & 77.97 & Normal \\
\hline$>1$ s/d +2SD & 1 & 1.69 & Gemuk \\
\hline$>2 S D$ & 4 & 6.78 & Obesitas \\
\hline Jumlah & 59 & 100 & \\
\hline
\end{tabular}

Dari tabel 3 di atas dapat diketahui bahwa terdapat 3 orang siswi (5.07\%) yang memiliki status gizi pada kategori sangat kurus dan 5 orang siswi (8.47\%) memiliki Status Gizi pada kategori kurus, sedangkan pada kategori normal terdapat sebanyak 46 orang siswi (77.97\%) dan 1 orang siswi (1.69\%) memiliki status gizi untuk kategori 
gemuk serta 4 orang siswa (6.78\%) memiliki status gizi dengan kategori obesitas. Untuk lebih jelasnya, distribusi frekuensi skor Status Gizi Siswi juga dapat dilihat pada histogram di bawah ini:

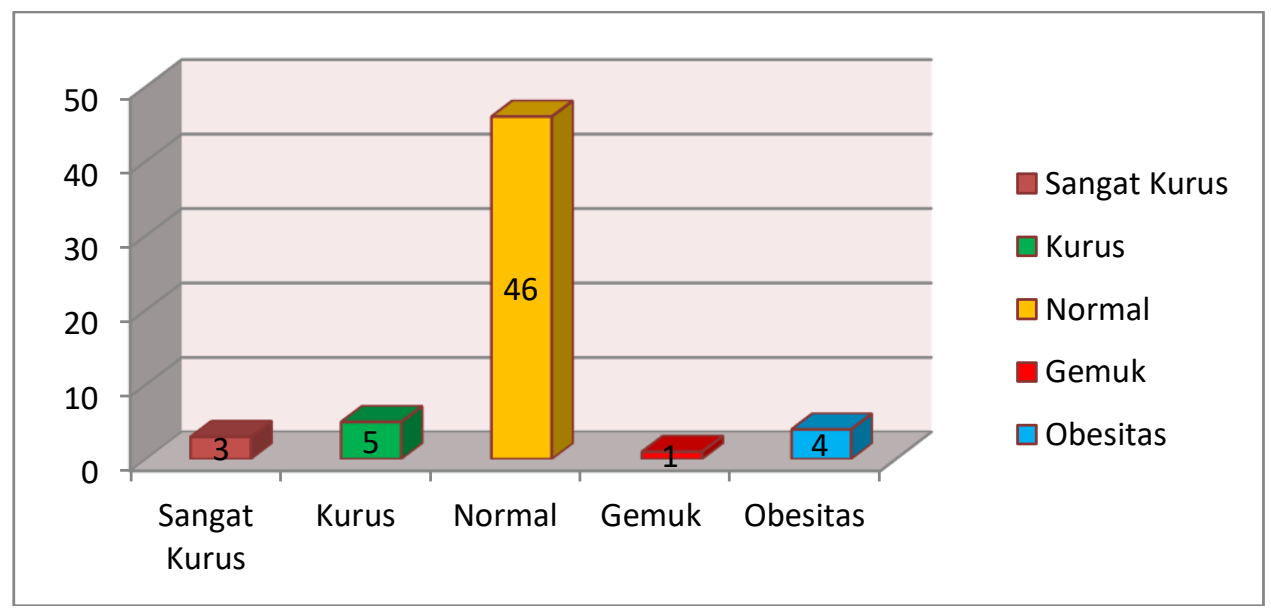

Grafik 1. Diagram Status Gizi Siswa Putri

\section{b. Pembahasan}

Berdasarkan pengukuran status gizi melalui pengukuran berat badan dan tinggi badan siswi sekolah dasar di Kenagarian Air Bangis yang telah dilakukan, maka hasil penelitian menunjukkan bahwa rata-rata keadaan status gizi siswi di Kenagarian Air Bangis Kabupaten Pasaman Barat berada pada kategori normal. Hal ini akan sangat mendukung untuk aktivitas siswi baik di sekolah maupun di luar sekolah. Status gizi yang dimiliki oleh siswa tersebut dapat dipengaruhi oleh beberapa hal diantaranya adalah:

1. Faktor Eksternal

Faktor eksternal yang mempengaruhi status gizi antara lain:

a. Pendapatan

Masalah gizi karena kemiskinan indikatornya adalah taraf ekonomi keluarga, yang hubungannya dengan daya beli yang dimiliki keluarga tersebut.

b. Pendidikan

Pendidikan gizi merupakan suatu proses merubah pengetahuan, sikap dan perilaku orang tua atau masyarakat untuk mewujudkan dengan status gizi yang baik.

c. Pekerjaan

Pekerjaan adalah sesuatu yang harus dilakukan terutama untuk menunjang kehidupan keluarganya. Bekerja umumnya merupakan kegiatan yang menyita waktu. Bekerja bagi ibu-ibu akan mempunyai pengaruh terhadap kehidupan keluarga.

d. Budaya

Budaya adalah suatu ciri khas, akan mempengaruhi tingkah laku dan kebiasaan seperti kebiasaan mengatur pola makan dengan baik.

2. Faktor Internal

Faktor Internal yang mempengaruhi status gizi antara lain:

a. Usia

Usia akan mempengaruhi kemampuan atau pengalaman yang dimiliki orang tua dalam pemberian nutrisi anak. 


\section{b. Kondisi Fisik}

Anak-anak yang kesehatannya buruk, adalah sangat rawan, karena pada periode hidup ini kebutuhan zat gizi digunakan untuk pertumbuhan cepat.

c. Infeksi

Infeksi dan demam dapat menyebabkan menurunnya nafsu makan atau menimbulkan kesulitan menelan dan mencerna makanan.

Sebagian besar siswi di sekolah dasar di Kenagarian Air Bangis sudah memiliki status gizi pada kategori gizi normal, akan tetapi masih ada beberapa yang memiliki status gizi pada kategori sangat kurus, kurus, gemuk serta obesitas (kelebihan berat badan). Hal ini tentu tidak berdampak positif bagi siswa dalam menjalankan aktivitasnya sehari-hari. Status gizi yang baik diperlukan oleh siswa dalam mendukung aktivitasnya sehari-hari. Siswa sebagai peserta didik memerlukan status gizi yang baik agar pertumbuhan fisik dan mentalnya dapat berjalan dengan baik serta memberikan pengaruh yang baik juga terhadap kesegaran jasmani siswa itu sendiri sebagaimana diungkapkan oleh Hardiansyah (2017) bahwa salah satu faktor yang menentukan kesegaran jasmani siswa adalah unsur status gizi, oleh sebab itu status gizi siswi penting untuk menjadi perhatian agar semua aktivitas siswi dapat dijalankan dengan maksimal baik itu kegiatan di sekolah maupun di rumah dan di lingkungan masyarakat.

Dari sekian banyak faktor yang dapat mempengaruhi keadaan status gizi siswi, faktor kebiasaan mengatur pola makan dengan baik dan kurangnya pendidikan gizi kemungkinan faktor yang menyebabkan masih adanya siswa yang memiliki status gizi pada kategori sangat kurus, kurus, gemuk dan obesitas. Hal ini disebabkan karena pada anak usia sekolah dasar banyak siswa yang tidak sarapan pagi serta memilih makan sesuai dengan keinginannya dan kesalahan orang tua dalam mengatur nutrisi pada anak usia sekolah dasar. Oleh sebab itu perlu diberikan perhatian yang lebih terhadap status gizi para siswa sekolah dasar, karena usia sekolah dasar merupakan usia emas untuk menentukan masa depan anak.

\section{SIMPULAN DAN SARAN Simpulan}

Berdasarkan pengumpulan dan analisis data yang telah dilakukan maka dapat ditarik simpulan dalam penelitian ini adalah sebagai berikut: sebagian besar status gizi siswi sekolah dasar di Kenagarian Air Bangis Kabupaten Pasaman Barat berada pada kategori normal dengan jumlah siswa sebanyak 46 orang dengan persentase sebesar $77.97 \%$.

\section{Saran}

Berdasarkan simpulan di atas, maka diajukan beberapa saran kepada:

1. Guru penjasorkes agar memberikan perhatian kepada siswa khususnya siswidalam melakukan aktivitas fisik di sekolah agar siswa mengalami pertumbuhan dan status gizi yang normal.

2. Orang tua agar lebih memperhatikan asupan gizi dan aktivitas yang dilakukan anak setiap hari agar anak terhindar dari penyakit dan gizi buruk.

\section{DAFTAR PUSTAKA}

Arikunto, Suharsimi. 2008. Prosedur Penelitian. Jakarta: Rineka Cipta 
Budiyanto, Agus krisno. 2001. Dasar-dasar Ilmu Gizi. UMM: Malang

Depkes RI. 1993. Pedoman Pengaturan Makan Atlet. Depkes: Jakarta 1997. Pedoman Umum Gizi Seimbang Untuk Remaja. Depkes: Jakarta 2000. Pedoman Pelatihan Gizi Olahraga Untuk Prestasi. Depkes: Jakarta 2003. Pedoman Pelatihan Gizi Olahraga Untuk Prestasi. Depkes: Jakarta

Hardiansyah Sefri. 2017. The Influence of Circuit Training Method on The Enhancement of Physical Fitness of Sports Education Department Students. Proceedings The $1^{\text {st }}$ Yogyakarta International Seminar on Health, Physical Education, and Sports Science: Yogyakarta.

Karyadi, Darwin dan Muhilal. 1996. Kecukupan Gizi Yang Dianjurkan. Gramedia: Jakarta

Khumadi. 1994. Bahan Pangan dan Olahan, Jakarta : Balai Pustaka.

Lisdiana. 1998. Waspada Terhadap Kelebihan dan Kekurangaan Gizi. Trubus: Ungaran

Marsetyo dan Kartasapoetra. 1991. Ilmu Gizi, Korelasi Gizi Kesehatan dan Produktivitas Kerja. Rineka Cipta: Jakarta

Sugiyono. 2008. Metode Penelitian Pendidikan. Bandung: Alfabeta

Undang-Undang RI No. 20 Tahun 2003. Sistem Pendidikan Nasional (2003). Jakarta: Cipta Jaya.

Winarno. 2011. Metodologi Penelitian Dalam Pendidikan Jasmani. Malang: Media Cakra Utama

Wirjatmadi, Bambang. 1998. Penilaian Status Gizi. IKM Unair: Surabaya 